\title{
On the ethical performance of female chivalry in the novels of Qing Dynasty
}

\author{
Ying Luo \\ (Sichuan vocational and technical college, Sichuan, Suining, 629000, China,Email: \\ 15181908638@163.com)
}

Keywords: female chivalry, orthodoxy, national spirit, loyalty, filial piety, view of chastity.

\begin{abstract}
As a special cultural phenomenon, chivalry is a comprehensive product of Chinese traditional culture, and has complicated relations with Confucianism, Taoism and ink. With the further strengthening of neo-confucianism in the qing dynasty, the female chivalric image in qing dynasty's novels focuses more on the ethical connotation of Confucianism. First of all, the female chivalry mostly showed the Confucian orthodoxy; On the other hand, the author hopes strongly subjective ideal, such as their national integrity, loyalty and filial piety, chastity view have vividly embodied in the body, the ethical color has been greatly strengthened, embodies the ethical tsunatsune the people to consciously safeguard and persuade the spirit of the world.
\end{abstract}

\section{Introduction}

In the feudal society of China, the role orientation of "women is in the right place, male is out of position" makes women mostly in male dependency status, without independent personality and self-consciousness. Opened the ancient Chinese literature, is everywhere is dissatisfied housewife weak female ethics elegy. In this ethical realm, the women's group is a "phenomenal" group, quite different from traditional women. "Man, is also" (Li Deyu of the Tang Dynasty "chivalrous theory")), the woman broke the specification "is on the inside", battle sword travel, rescue, added a few minutes to weak sorrowful but women world masculine energy. From the cultural origin, woman this rebellious, free and easy attitude towards life, battle righteousness line man holding a rough, ethos, and magic unpredictable fencing with spells, etc., mainly affected by the ink, two thinking results. But no matter how out of the ordinary woman, how the writer of curiosity or rebellion, they Chinese from traditional literati in the Confucian ethics in them still more or less reflected; especially after the rise of Neo Confucianism in the Song Dynasty, chivalrous women ethical color increasingly deepened, the Qing Dynasty reached the point to reach the peak of perfection. This paper tries to discuss the ethical color of female chivalry in Qing Dynasty.

As early as the Han Dynasty, with Dong Zhongshu in the "heaven and man" on the basis of the qualitative proposed "three cardinal guides" and promote, those for women with a "three", from "four virtues", "seven" ethics has been formed, female education has gradually formed a systematic theory; but relatively these, in real life, the impact is not too large. Especially in the free and open Tang Dynasty, the restrictions on women were more relaxed, so the chivalrous women in the Tang Dynasty were free and rebellious, free and free, and were not bound by the Confucian ethics. Especially in the open and open Tang Dynasty, the restraint of ritual on women is more relaxed. Therefore, the chivalrous men in Tang Dynasty are more free and rebellious, free from restraint and restricted by Confucian ethics. In the Song Dynasty, with the rise of Neo-Confucianism, feudal ethics gradually strengthened in the real society, and the moral and moral color of the female chivalry in song novels began to appear, and it became more and more intense. Such as Hong Mai's solution to the new husband and his four concubines, Fu as children; "business news" in the female sword to concubine, Jiang's wife and sisters; "the uncle in" my man "in the fairy ghost, the heart rate of loyalty" chivalry woman. The relative Tang woman, woman image in the novels of Song Dynasty to the Ming Dynasty legend greatly reduced, greatly enriched the color of family ethics, filial piety and chastity and began to embody the spirit connotation of opening and cleaning woman ethics precedent. 
In the Song Dynasty, the status of Neo-Confucianism rose gradually; to the Ming dynasty was authorized as official philosophy; in the Qing Dynasty, Zhu Xi's position in the official position was even higher. Kang Xi had personally presided over writing sex principle and substance, "Zhu Xi's encyclopedia", Repute Zhu Xi "Mio dry in one hundred, becoming a study, a simple and stand than ambient arbitrary" ("The imperial order of the book of Zhu Xi"). Under the advocate of science, in a dominant position in the field of ideology, maintaining the feudal laws, the consolidation of the feudal autocratic rule, Confucian ethics culture promotion into the most mature period. Neo-Confucianism was promoted to the supreme spiritual realm, and enlightenment became an important policy of governing the country. "The people who treat the people first. Teach, not from, and then with the law."[1] Emperor Qianlong emphasized the poetry of "gentle and thick" and emphasized the social function of literature education. During this period, the women's education was greatly promoted, and the court praised the virtuous woman, the great tree chastity archway, and the high young lady. Under this social environment edification, scholars formed a strong education psychology, even for "very" woman image in that is also very strong ethical color pen, reflects the writers consciously maintenance to the laws of Confucian ethics and advised the spirit. Compared with the female characters in the novels of the previous generation, the ethical tendency of female chivalry in Qing Dynasty novels is more prominent, which reflects the characteristics of the female chivalry's emphasis on the connotation of Confucian ethics.

\section{The main argument}

\section{The female chivalry embodies the orthodox concept of Confucianism.}

In literary history, everything is done with "man to break prohibition", Sima Qian also said the man "the adults is irregular on justice", all that man has a rebellious spirit, its morality goes against the feudal ethics. For example, the chivalrous chivalry in the Tang Dynasty is flexible and free, with a strong sense of self. But in the Qing Dynasty writer writing, fundamental changes have taken place in the woman's chivalrous spirit, they abandoned the Tang woman man for optional sex and sex, but according to the Confucian orthodoxy which gives its legitimate justice.

For the vengeance, the novel always emphasizes the former cause of the female chivalrous family being killed by injustice, so as to highlight the justice of the vengeance of the women. If the father is the Qin officer Haozu slaves beat to death, only the Qin officer Nvbannanzhuang revenge story; Geng Niang saw family innocent victims of the scene, only age woman Shouren enemy story; Qi Wujiu concubine, father of odd injustice is impressive, concubine incognito revenge story; powder princess the father of a traitor to the victims, to fly into the princess's story designed to kill corrupt officials. Compared with the Tang Dynasty woman, as a wife, concubine Cui Jia Shensi only words of revenge, without saying why revenge, revenge of the Qing Dynasty woman has more natural justice. The object of punishment is always generous woman or greed, or violence, or prostitution, or they are evil, justice and chivalry. Such as air warning and Tanbao is free; and laundry punish is arrogant and wilful acts; Jinling Women's disciplinary overbearing acts of adultery longitudinal updo; nun is kill harm Party A. A woman is to repay the incorruptible official, such as "Shen Qifeng" in Yi Budao book, Wu Xiang Han Nie Er's Sun Zhuang Gu, under the pen of Xu Ke Ni Huigu willing servant concubine, guard killing the pirates, repay the benefactor is his father morally unjust case.

Even the theft, the author also try to emphasize its strong desire to steal the frustration and desire to convert to the right, Confucian orthodoxy is distinct. As the city is to steal Princess powder because his father was a traitor against a slain, forced to flee to overseas to steal; "Yao Yunxian" in Wu Xiuluan for the pirates, because a father resigned and died, helpless to steal away. In the absence of opportunities, the woman will always seize the opportune moment convert way. Such as Wang Tao "stealing girl" in theft Qian pearl and Lv Mucheng after marriage, husband to personal fame, when thinking from the fen. The stolen grotto, living in the Encore? The Lang is quick to make the return, the concubine wishes to be from. " The Confucian thought of fame, and remarkable achievements. Shen Qifeng "evil" in one Lu Sheng wife abandoned family, insurance four, risked their lives to stay away from the stolen grotto, with her husband to return home, the performance of women's 
consciousness of feudal married husband with her husband, on the other hand also showed a strong desire to desire to convert right theft.

\section{The new historical mission of female xia: justice and national integrity.}

Tang woman, or for his family to revenge, or to the grace of others, and more for the individual to do the chivalrous. Among them, Nie Yinniang and lady of that red has in getting rid of the aesthetic value; but from the creator's subjective intention, they mainly serve as Master Assassin or bodyguards, and not really focus on social situation or common people, is the main purpose of Tang wonen chivalry, confined to small range of " individual". After that, the novels of the Song, Yuan and Ming women were more integrated into the war and homesickness, and the strength of the social criticism was increasing. To the Qing Dynasty, female chivalry cruel and pacify the good people in classical novels increased the amount of social criticism efforts greatly enhanced. In addition to their corruption or violence, punish, such as sword kill red gauze female updo, thieves steal beads and yellow alert Tanbao CPIC, operating out of cash arrogant and wilful punishment Fu Jun the laundry women, theft of gold rich famine relief, the slave Zhang Qing designed to kill corrupt officials, warning her Princess Pink City longitudinal in expensive Jinling Women; they or demon in addition to blame, people from harm, such as the song "Tong Jie Hao Changbai" school and the sword fairy fox in middle-aged women, under the pen of Wang Tao beheaded the sword Dragon Mountain Lake Nie Biyun. The original is personal and man's ego feelings gradually sublimate to common people and the big man my feelings, for the purpose of man woman from "for change" to "going to the world". The so-called "small and uneven in the chest, can be poured out of wine; the world is unequal, not the sword can not be sold." [2]The people borrow under the pen of woman image, symbolizes the strong eradication of grievances, chivalrous spirit of positive ideal.

Some of the women in the national disaster, the country, also showed the unusual home country's worries and national gas festival. As the Qiu Xing's " female chivalry Niang Cui Yunniang's biography,"[3] has created a country to the death of a country to fight against the image of female chivalry. Cui Yunniang with the father, the two people were falsely accused of being arrested by foreigners, suffering. After the release, the woman angrily joined the boxer rebellion against the foreigners. After the Allied forces joined the Beijing division, the female warrior Cui Yunniang inspired and led the group to fight the west soldier bravely, and then the long sword of the people in the group of the people to seek the honor, the author expressed his strong sense of national identity and national integrity. $\mathrm{Xu} \mathrm{Ke}$, whose novel named"deng jiane's throwing Russia will be in the ground"and "deng jioue out finns in death"[4], both of them are about the woman, Deng Jiane. Jiane sword martial arts, Russia will want to make the sword fall to the ground, I was a weak woman, can not insult the heroic sword; e to Russia the feast, Accor reserved, all different, a weak woman not weakness demeanor; Russia will send the Chinese service to perform the funeral of my husband the mother of the sword sword e, e have sent to earth to show own grave, respect and friendship for the victims, but also reflects the weak female self-esteem, cherish their national integrity.

Qing classical Chinese novels for a lot of good integrity, carry, rich nation woman appeared, it serves to show the people increasingly gifted woman new historical mission, woman image of sex than previous generations embodies the greatly strengthened.

The concept of "loyalty and filial piety" of women.

Qing classical Chinese martial arts novels although short, the plot is relatively simple; but in the brief narration, the author will always can't help the Confucian tradition of "filial piety" concept into the woman image. Carefully examine the Qing Dynasty generous as by as evil woman, has the tendency of "the corrupt official is the emperor". Empty front-around Huang Taibao, and one of its list of crimes for "carry with deceit gentleman on"; the princess of powder city killed corrupt officials, but "the green forest, but still have the heart of loyalty"; Jinling Women's disciplinary longitudinal towards expensive, advised its patriotic, the essence of woman reflects the "loyalty" trait. In Liu Jun's "Yang E Biography", Yang E is a master of the typical woman loyalty. In the novel, Yang e's family is devoted to the Lord, and Yang e, as a woman's generation, is even more inspiring. During the reign of emperor Yongming, she and her husband were displaced and protected; After the king of Yongming was killed by wu sangui, her husband also died of grief and indignation. Although she was 
very weak, she still in the satrap's west to close to Wu Sangui to sell liquor, color art, spare no effort as revenge. It is in utter devotion. Wu Sangui was a concubine, but she was very ill and died. Can be described as "perishing before victory, long the hero tearful, tragic.

One hundred lines of filial piety. "The source of the hundred lines of filial piety, and the first of the female virtues." (Wang Jiefu "female fan Jielu - filial piety"). In strongly advocated filial piety in qing dynasty, literati's woman image "filial piety", mainly has the following three conditions: first, there is at the expense of their type, for father revenge, such as Pu Songling's business officer, chivalry female, Zeng Yandong's Qi Wujiu's wife and so on. When the father was taken after the disaster, they will love and life are indifferent, the only reason to be alive is to revenge. Taking the three officer of the marriage can be happy, and the Swordswomen Gu Shengxi knot, Qi Wujiu's concubine and her husband and son also can live happily, but they would not hesitate to choose the difficult path of revenge. Their father for revenge, or sacrifice love, or sacrifice, is filial piety. Second is the stuff for the father, such as gratitude, gratitude, Sun Zhuanggu, Nie nvxia shu'er Ni Huigu. This kind of woman because father didn't have his official, in order to repay, and as the father sent by official odalisk. Female to secretly protect the Lord, for the father of Baoen; even the master suffered abuse, nor ingratitude. They are my father as a gift with friends, no complaints; at the expense of their youth and love for the father, gratitude, is also a big filial. Of course, from another point of view, this kind of female chivalrous man is deeply bound by feudal ethics and lacks personality. The question of marriage they characterized by patriarchal, submissive woman, otherworldly spirit reflects the male perspective greatly reduced, scholar's view of women. The third category is the attentive attentive mother type. As Pu Songling's heroines failed to avenge, because the mother in the hall; despite the tough life, but still his mother until the mother died, paternity; Li report big enemy. And as the "Abseiled Swordswomen" Hui Niang when mother was ill, because there is no money for treatment, such as medicine for female cutting stock. These all vividly show a filial piety of the woman. The woman or the father for revenge, or gratitude for the father, mother or his paternity, embody the woman's filial piety, with strong ethical color.

\section{Women's view of "chastity".}

It is a small thing to starve to death. The idea of chastity is more obvious in the women of the Qing Dynasty. In the novels of the Qing Dynasty, most of the female chivalrous snow has their body. Zheng Xuan Ding's mother living, but no one can make your children swim, "arm Shougong Sha can experience the chastity of ear"[5]. Pu Songling's revenge, the vengeance of the heengniang, in order to avenge, and revenge, false from it, in the new wedding night hand blade enemy, the female chivalrous is always the body of ice and snow. Even the female chivalrous who is a prostitute is all the ice and snow. Such as Li Siniang who Wang Tao created, " is a female prostitute, who is a prostitute, but is not known for the beauty of the moon, and the snow and ice." [6]You Yang's "female thief biography" in the theft of the black prostitute, his father as leader of them, female perennial as the father of bait, lure customers past; but his daughter's body is very strict, with the chaos of the spur of the moment, "the edge of this still virgin".

For those who are self-reliant and frivolous, women hate to cut their teeth and punish them severely. If the sodomy girl wants to be a girl, she will be stabbed by the sword. The evil night in the high bun, the result is thrown by the Nineveh; The iron leg han chang plays the beautiful woman, the result is tied up by the woman; The son of the army wants to be the mother of the cloud niang, the result of the risk to be killed by yunniang dao. Those who are frivolous and frivolous, or have been beaten down and fled, or the death of the yellow spring, not to take the women's half of the cheap. This not only highlighted the chivalrous martial arts of women, but also reflects the woman's clean body. The article is devoted to women's punishment of the crime of women, and it is also noted that the men's right of view of the women's consciousness of women's chastity is maintained and appreciated.

In addition, the trend is also very prominent as an understanding wife and loving mother. As a notable Swordswomen, good cooking and laundry, embroidery work of the woman Qiu Xiaojuan, leaning against the light shoe support system etc. all female dart woman, smart, full of folk women's life. The "two women wait on one man" rule also implements the woman in the body.Such as the 
Tang Geng Niang and Shigong Shi Jinsheng; and Wang Tao " swordsman and lanbin in the pearl of the sword"; "the sisters" in the Slave Slave sisters were Shi He Sheng. The woman rebellious spirit greatly weakened, the ancient traces of heavy shackles.

\section{Conclusion}

To sum up, theQing literati's woman image not only martial arts, chivalrous, full of " chivalry ", but also pay attention to the common people, harmony, filial piety and chastity, respect from, full of the "truth" of confucianism. The people through the legendary practices of " chivalry " and "truth" of the full integration of the dual ideal woman image as they borrow "Knight" and "Enlightenment", with strong signs of the times. This is closely related to the weakness of the late qing dynasty and the darkness of social chaos. On the other hand, it is the direct result of further strengthening of neo-confucianism in the qing dynasty. Although the woman from the face of a propriety shaped woman image has certain restraint, affects the woman free spirit, the woman lack of personality; but the woman concerned about country and people in my feelings, the woman who chivalry from the personal grudges to the world just changed, the woman beyond self has a positive meaning. "The chivalrous person, for the state and the people", which has some influence on the contemporary novels in those with great responsibility for shaping the image of the woman.

\section{Acknowledgments}

Fund project :This article is one of the research achievements of the research on female chivalry in the qing dynasty wuxia novels by the humanities and social science department of sichuan education department. (project number:13SA0047)

\section{References}

[1]Department of history, sichuan university, sichuan university, sichuan university press, August 13, 2007, sichuan university press, 1996, page 444.

[2]High tide, sun baohe's translation of "the dream", zhongzhou ancient books publishing house, 2005, page 136

[3](qing) the anthology of the anthology series of the five episodes of the anthology series, the people's literature publishing house, 1994, page 1425.

[4] (qing) xu ke, the sixth volume of the Japanese millet, the Chinese book bureau, 2003, page 2998, 2844.

[5] (qing) xuanding "the night rain and autumn lamp record", Shanghai ancient books publishing house, 1987, page 598.

[6] (qing) wang tao, wang siyu, "the song of the song", vol. 4, people's literature publishing house, 1999, page 178. 